\title{
NEW POSTCRANIAL REMAINS OF SMILODON POPULATOR LUND, 1842 FROM SOUTH-CENTRAL BRAZIL
}

\author{
MARIELA CORDEIRO DE CASTRO \\ Programa de Pós-Graduação em Biologia Comparada, Departamento de Biologia, FFCLRP-USP, Av. dos Bandeirantes, 3900, \\ 14040-901, Ribeirão Preto, SP, Brazil.marielaccastro@yahoo.com.br \\ MAX CARDOSO LANGER \\ Laboratório de Paleontologia, Departamento de Biologia, FFCLRP-USP, Av. dos Bandeirantes, 3900, 14040-901, Ribeirão \\ Preto, SP, Brazil.mclanger@ffclrp.usp.br
}

\begin{abstract}
The postcranial remains of the saber-toothed cat Smilodon populator dealt with here corresponds to the first occurrence of the taxon in the State of São Paulo, filling a gap in its geographical distribution. The fossils were collected in Abismo Iguatemi, a karstic fissure located in the municipality of Apiaí, upper Ribeira River valley. Given that the described specimens share equivalent size, similar preservation, and were found relatively close to one another, without duplicated elements, it is suggested that these belong to a single individual. Concerning the accumulation, this animal might have entered the fissure partially or completely articulated, either trapped or dragged by pluvial flood as a carcass. In this context, the fragmentation and weathering of the fossils seem related to reworking inside the cave. Comparative measurements show that the studied material dimension is, on average, larger than North American forms and approximate to other South American specimens, that are admittedly larger and more robust.
\end{abstract}

Key words: Smilodon populator, megafauna, Quaternary, Abismo Iguatemi, São Paulo State, Brazil.

RESUMO - Os elementos pós-cranianos do tigre-dentes-de-sabre Smilodon populator aqui tratados correspondem à primeira ocorrência do táxon no estado de São Paulo, o que vem a preencher uma lacuna em sua distribuição geográfica. Os fósseis provêm do Abismo Iguatemi, depressão de origem cárstica localizada no município de Apiaí, Alto Vale do Ribeira. Dado que os elementos esqueletais apresentam tamanho equivalente, preservação similar e foram encontrados próximos uns aos outros, sem elementos duplicados, assume-se que pertençam a um único indivíduo. Quanto ao modo de acumulação, infere-se que o material tenha adentrado o abismo parcial ou completamente articulado, por queda acidental do animal ainda vivo ou arraste da carcaça pela água pluvial. Neste contexto, a fragmentação/abrasão dos fósseis se relacionaria ao retrabalhamento dentro da caverna. Medidas comparativas revelaram que as dimensões do material estudado são, em média, maiores que aquelas de formas norte americanas e aproximam-se daquelas de outros espécimes sul americanos, reconhecidamente maiores e mais robustos.

Palavras-chave: Smilodon populator, megafauna, Quaternário, Abismo Iguatemi, São Paulo, Brasil.

\section{INTRODUCTION}

The South American saber-toothed cat is known since the middle of the $19^{\text {th }}$ century (Lund, 1842), and represents one of the better known components of the Quaternary faunas of that continent (Burmeister, 1866; Churcher, 1967; Berta, 1985). In Brazil it has been registered in Pleistocene-Holocene deposits of Minas Gerais (Paula-Couto, 1980a; Piló \& Neves, 2003), Paraíba (Paula-Couto, 1980b), Ceará (Paula-Couto, 1980b; Gomide et al., 1987; Bergqvist et al., 1997), Goiás (Gomide et al., 1987), Bahia (Cartelle \& Abuhid, 1989; Cartelle \& Hartwig, 1996; Lessa et al., 1998), Rio Grande do Sul (Lessa et al., 1998; Rodrigues et al., 2004), Rio Grande do Norte
(Lessa et al., 1998; Porpino et al., 2004), Piauí (Guerin et al., 1999), Pernambuco (Silva et al., 2003) and Sergipe (Dantas et al., 2003; Dantas \& Zucon, 2004). The studied material corresponds to the first occurrence of a saber-toothed cat in São Paulo State (Ferreira \& Karmann, 2002; Hingst-Zaher et al., 2003; Castro, 2005), filling a gap in the geographical distribution of these animals.

The species composition of the genus Smilodon is controversial. Paula-Couto (1979) defined a single species, S. populator Lund, 1842, with two subspecies, S. populator populator and S. populator californicus, respectively corresponding to the South and North American members of the genus. Other authors (e.g., Kurtén \& Anderson, 1980) 


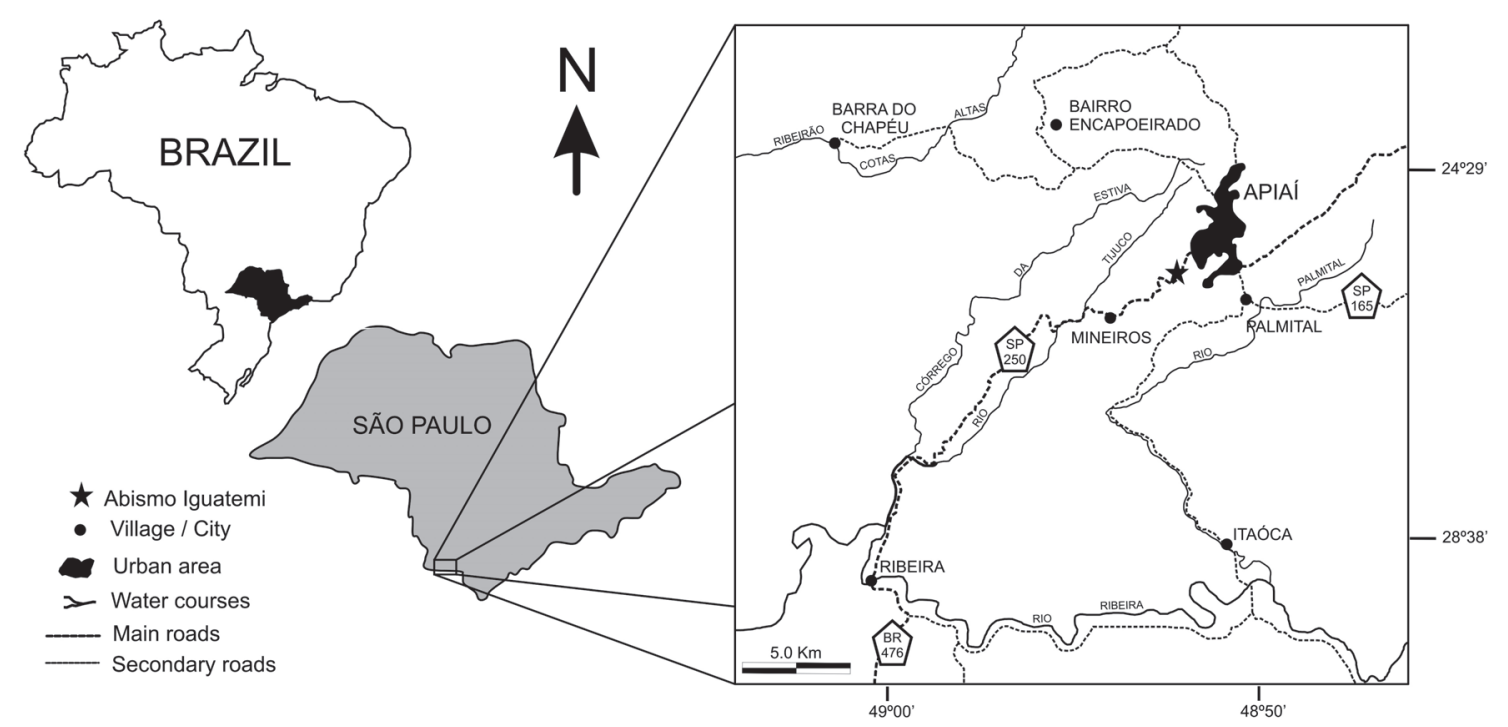

Figure 1. Location map of Abismo Iguatemi locality, in São Paulo State, Brazil.

accept a specific differentiation between these forms, applying the name $S$. fatalis Leidy, 1869 , to the North American form, given its priority over S. californicus Bovard, 1907. More recently, S. gracilis Cope, 1880 was acknowledged as a third and more basal taxon, restricted to the Late Pliocene-Middle Pleistocene of North America (Kurtén \& Werdelin, 1990). This paper will adopt the scheme proposed by Berta (1985), in which Smilodon populator represents the only South American saber-toothed cat. In any case, even in the threespecies scheme proposed by Kurtén \& Werdelin (1990), all the cis-Andean Smilodon forms (including the Brazilian ones) are referred to $S$. populator. The nomenclatural status of $S$. populator is also questionable (see Burmeister, 1866; Lund, 1950; Churcher, 1967), given the possible priority of other specific names such as "Hyaena" neogaea Lund, 1839 and "Felis" protopanther Lund, 1839. Yet, we will follow the orthodoxy (Paula-Couto, 1979; Berta, 1985; Kurtén \& Werdelin, 1990) and refer the Brazilian saber-toothed cat to $S$. populator.

The fossils described here have been collected in the 44 $\mathrm{m}$ in plan and $15 \mathrm{~m}$ deep karstic fissure known as Abismo Iguatemi (Figure 1). This was formed in the intensively folded rocks of the Açungui Group (Middle Proterozoic) that includes metamorphized dolomitic limestones intercalated with insoluble lithologies (Auler \& Farrant, 1996). The fissure was initially explored by Ferreira \& Karmann (2002), who named the site and retrieved paleontological material, including a skull and both mandibular rami possibly associated with the specimens described herein. This skull presents prominent post-orbital process, long post-canine diastema, and absence of the second premolar teeth (Hingst-Zaher et al., 2003). The cave deposits are mainly composed of a black to reddish clay associated with larger clasts of limestone, filite and calcite crusts. Concerning the age of this material, recent $\mathrm{C}^{14} \mathrm{AMS}$ (Accelerator Mass Spectrometry) dates of Smilodon populator were given as 14,580 years BP (Alex Hubbe; verbal comm. 30/05/2008).

\section{MATERIAL AND METHODS}

The skeletal remains described here were collected by members of the Museu de Zoologia of the Universidade de São Paulo and are deposited at the fossil collection (MZSP) of that institution. Given the rarity of comprehensive osteological descriptions of Brazilian saber-toothed cats (Cartelle \& Abuhid, 1989), the main reference adopted for anatomical nomenclature and measurements was the study of Merriam \& Stock (1932) on S. fatalis from Rancho La Brea, with complementary data from Cartelle \& Abuhid (1989) and Rodrigues et al. (2004). For anatomical terminology, Nomina Anatomica Veterinaria (ICVGAN, 2005) was followed whenever possible.

\section{SYSTEMATIC PALEONTOLOGY}

\author{
CARNIVORA Bowdich, 1821 \\ FELIDAE Fischer, 1817 \\ MACHAIRODONTINAE Gill, 1872 \\ Smilodon populator Lund, 1842 \\ (Figures 2-5, Tables 1-3)
}

Specific assignation. The diagnosis of S. populator (PaulaCouto, 1955; Berta, 1985; Kurtén \& Werdelin, 1990) includes characters that can not be observed in the specimens of Abismo Iguatemi. However, the possibly associated skull falls into the morphometric range of that taxon (Hingst-Zaher et al., 2003). Additionally, Paula-Couto (1955) stated that the South American saber-toothed cats usually have longer and stouter long bones than those of North America, a condition observed in the material described here.

Material. MZSP-PV 07, 08, thoracic vertebrae; MZSP-PV 0914, 16, 18, 19, 21, ribs; MZSP-PV 05, right ulna; MZSP-PV 04 left radius; MZSP-PV 02,03 left and right innominates; MZSPPV 01, left femur; MZSP-PV 06, right astragalus. MZSP-PV $15,17,20$, anatomically indeterminate elements that may not 


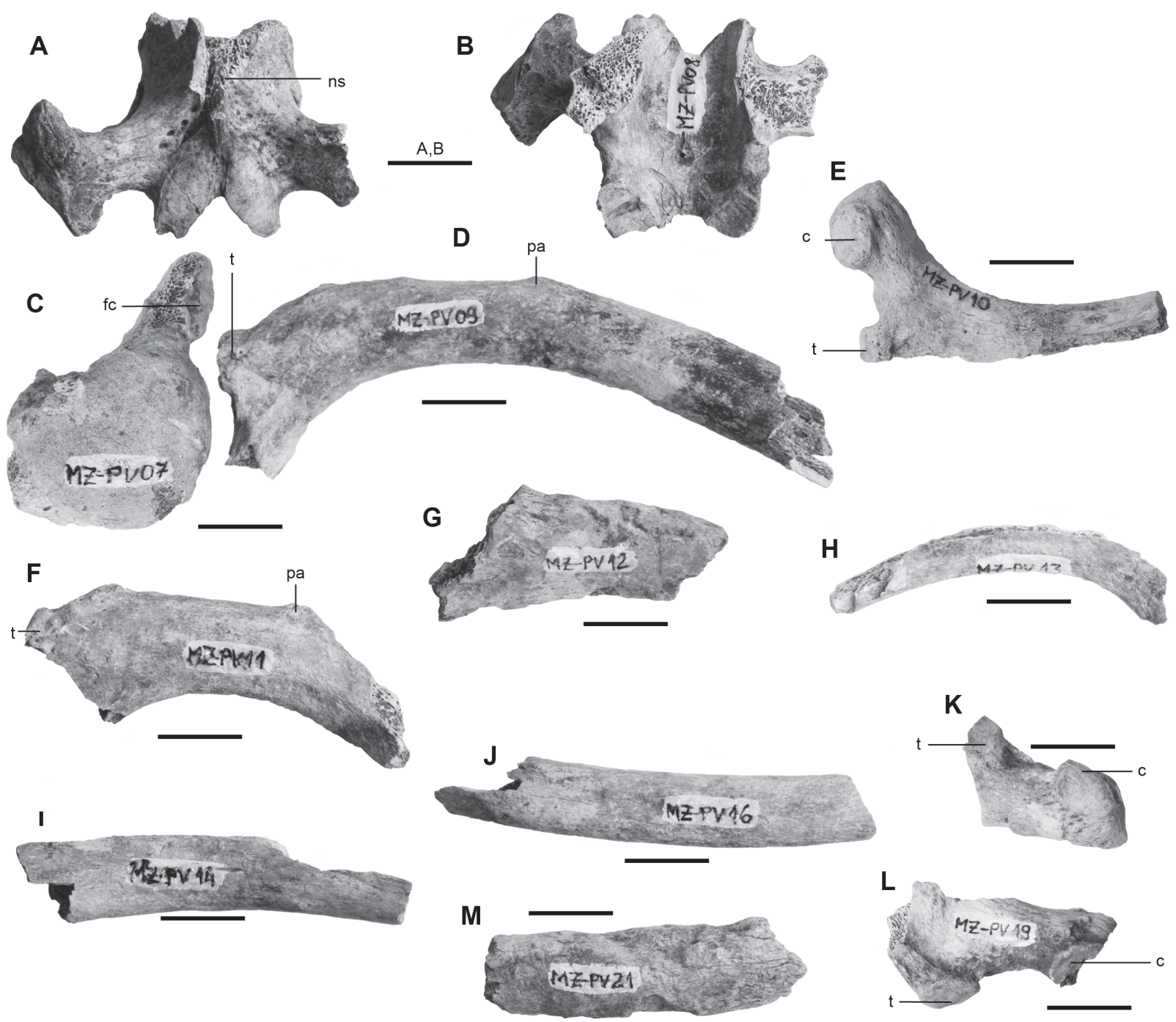

Figure 2. Smilodon populator from Abismo Iguatemi, vertebrae $(A-C)$ and rib fragments (D-M): A-B, MZSP-PV 08 in dorsal (A) and ventral (B) views; C, MZSP-PV 07; D, MZSP-PV 09; E, MZSP-PV 10; F, MZSP-PV 11; G, MZSP-PV 12 (C-G in cranial view); H, MZSP-PV 13; I, MZSP-PV 14; J, MZSP-PV 16; K, MZSP-PV18 in caudal view; L, MZSP-PV19 in cranial view; M, MZSP-PV 21. Abbreviations: c, capitulum; fc, facet for the capitulum of rib; ns, neural spine; pa, posterior angle; t, tuberculum. Scale bars $=20 \mathrm{~mm}$.

belong to $S$. populator, although they were found together with the other specimens and share similar preservation. Locality. Abismo Iguatemi, about $5 \mathrm{~km}$ southwest of Apiai town, upper Ribeira River valley, São Paulo State, Brazil (Figure 1).

\section{DESCRIPTION}

\section{Thoracic vertebrae}

Two thoracic vertebrae were collected: MZSP-PV 07 preserves most of the cranial portion of the centrum, and MZSP-PV 08 is a partial neural arch (Figure 2). The cranial articular surface of MZSP-PV 07 is nearly complete, together with the left facet for the capitulum of rib, the position of which suggests its identification as a mid thoracic vertebra. The ventral tip of the caudal articulation is preserved, allowing the measurement of the centrum length as $45 \mathrm{~mm}$. A large nutrient foramen (about $7 \mathrm{~mm}$ wide) occurs in the center of the dorsal surface, as also seen in some specimens described by Merriam \& Stock (1932). A 2 mm wide foramen is seen in the center of the opposite (ventral) surface.
MZSP-PV 08 preserves incomplete neural spine and left transverse process, somewhat fragmented pre- and postzygapophyses, a nearly complete right transverse process with articular facet for the tuberculum, and part of the right articulation for the capitulum of rib. Series of foramina are present on the dorsal surface, flanking both sides of the neural spine: four on the right and three, more spaced, on the left. Another foramen is seen on the mid-caudal part of the ventral surface. The transverse process is more caudally projected than the pre-zygapophyses, which are just $15 \mathrm{~mm}$ apart from one another at their cranial tips. This suggests that MZ-PV 08 represents a caudal thoracic vertebra (see Merriam \& Stock, 1932), although some variation might be expected.

\section{Ribs}

Ten rib fragments were recovered (Figure 2). Four of them (MZSP-PV13, 14, 16, 21) are non-articular shaft segments recognized as ribs only due to their cranial-caudal flattening. The others preserve dorsal portions of left (MZSP-PV 09, 11, 
12) or right (MZSP-PV 10, 18, 19) ribs. The capitulum has two articular surfaces separated by a shallow notch, and the tuberculum includes the articular portion and a small lateral projection. The surface between tuberculum and capitulum is more excavated in MZSP-PV 10 and MZSP-PV 18. In the former, the caudal portion of that surface bears a tuberosity dorsal to a roughened area, while in the latter that portion possesses a number of foramina. The posterior angle is preserved in specimens MZSP-PV 9 and MZSP-PV 11.

\section{Ulna}

The partial right ulna (MZSP-PV 05) is broken at the distal portion of the interosseus ligament scar, so that about $70 \%$ of the bone is preserved (Figure 3). Also fragmented are the lateral surface of the olecranon, the tip of the coronoid process, and the cranial portion of the articular surface for the radius. Distal to the latter, a flattened area in the diaphysis represents the origin of the supinator muscle. A prominent tubercle is seen distal to the coronoid process. Lateral to this a large nutrient foramen is seen, whereas other foramina spread over the epiphysis and around the proximal portion of the sigmoid cavity.

\section{Radius}

The well preserved left radius (MZSP-PV 04) lacks only the proximal epiphysis and a small medial portion of the distal articulation (Figure 3), precluding the observation of grooves for $\mathrm{mm}$. extensor ossis metacarpi pollicis and extensor communis digitorum. A wide nutrient foramen perforates the medial surface of the proximal-most part of the shaft, distal to which is located the tubercle for $\mathrm{m}$. biceps brachialis. The middle part of the shaft is laterally flattened for the insertion of m. supinator. As pointed out by Merriam \& Stock (1932),

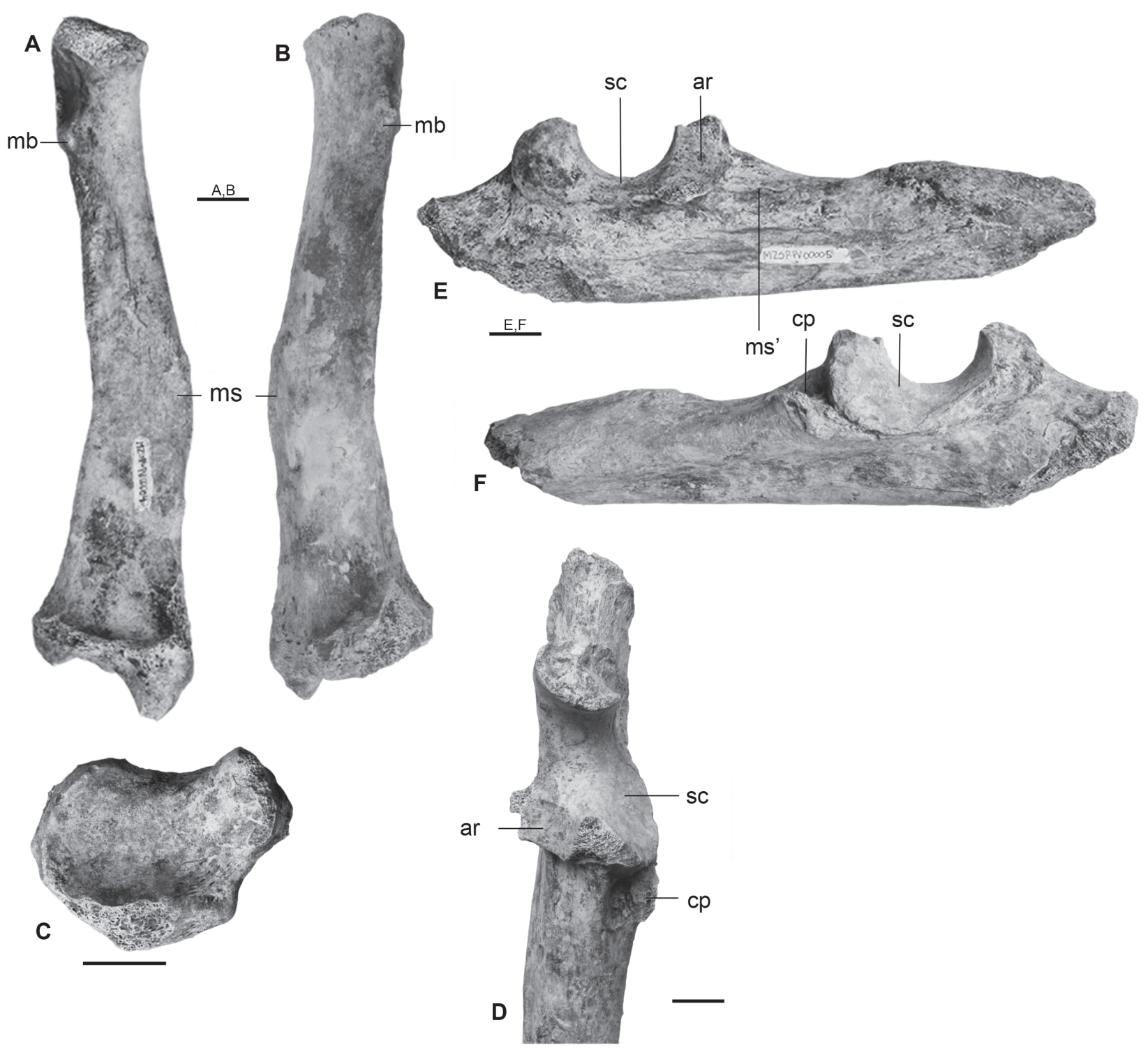

Figure 3. Smilodon populator from Abismo Iguatemi. A-C, MZSP-PV 04, left radius in cranial (A), caudal (B) and distal (C) views; D-F, MZSP-PV 05, right ulna in medial (D), cranial (E) and caudal (F) views. Abbreviations: ar, articulation for the radius; $\mathbf{c p}$, coronoid process; $\mathbf{m b}$, tubercle for $\mathrm{m}$. biceps brachialis; $\mathbf{m s}$, flatness for the $\mathrm{m}$. supinator; $\mathbf{m s}$ ', origin of $\mathrm{m}$. supinator; sc, sigmoid cavity. Scale bars $=100 \mathrm{~mm}$. 

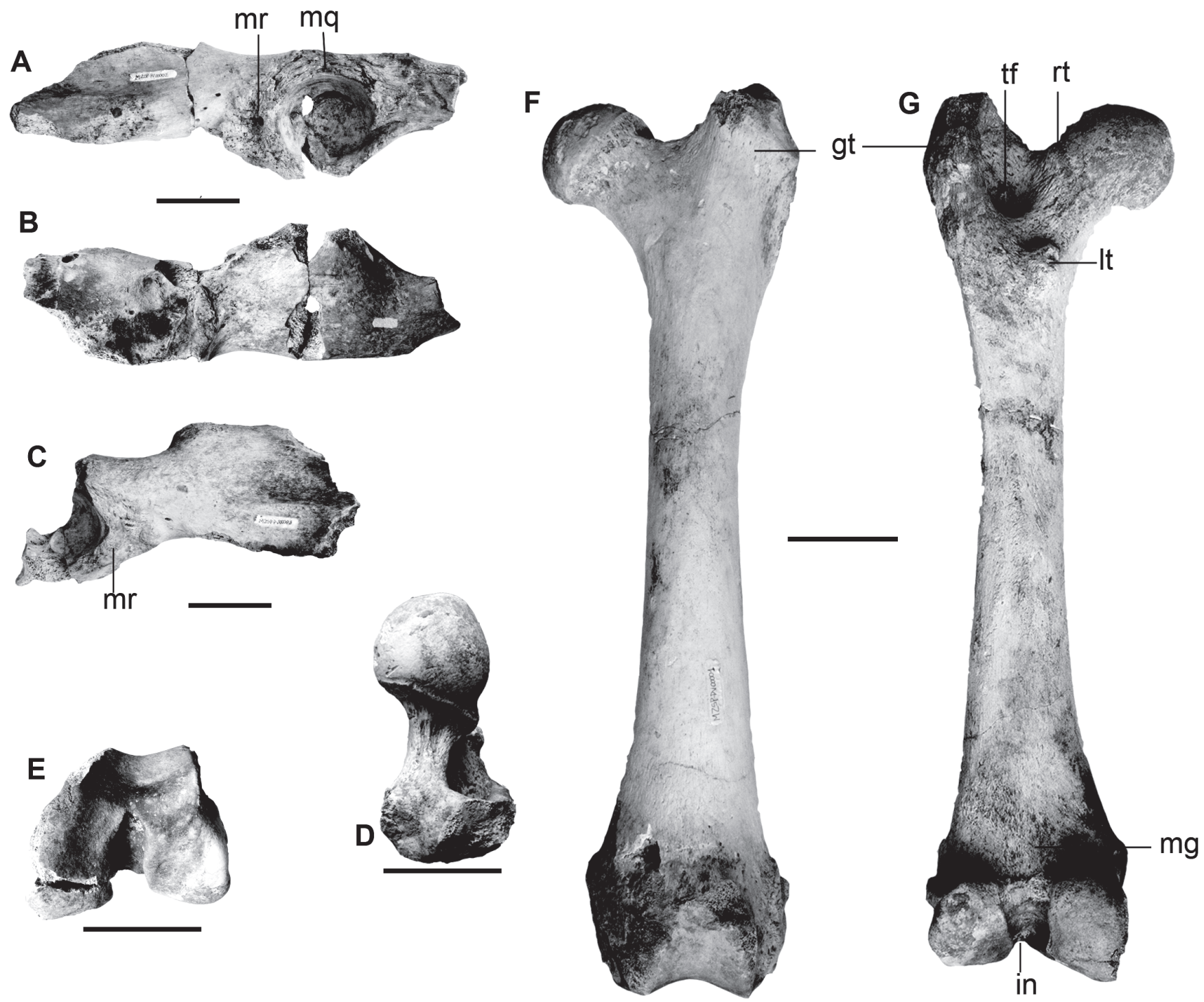

Figure 4. Smilodon populator from Abismo Iguatemi. A-B, MZSP-PV 02, left innominate in lateral (A) and medial (B) views; C, MZSP-PV 03, right innominate in lateral view; D-G, MZSP-PV 01, left femur in proximal (D), distal (E), cranial (F) and caudal (G) views. Abbreviations: $\mathbf{g t}$, greater trochanter; in, intercondylar notch; It, lesser trochanter; $\mathbf{m g}$, origins of $\mathrm{m}$. gastrocnemius; mq, origin of $\mathrm{m}$. quadratus femoris; $\mathrm{mr}$, origin of $\mathrm{m}$. rectus femoris; $\mathbf{m v}$, scar for the $\mathrm{m}$. vastus intermedius; $\mathbf{r t}$, rounded tuberosity; tf, trochanteric fossa. Scale bars $=50 \mathrm{~mm}$.

the radius is distinctively stouter than that of modern large felines, especially in the distal half of the bone. The groove for $\mathrm{mm}$. extensor carpi radialis longus and brevis is broad and deep.

\section{Pelvis}

The left innominate (MZSP-PV 02) preserves the ilium (except the dorsocranial margin of the crest), the cranial half of the ischium, and the acetabular portion of the pubis (Figure 4). A prominent rugose surface for the origin of m. rectus femoris is seen cranial to the iliac rim of the acetabulum, dorsocranial to which lie three wide nutrient foramina. Caudal to the ischiatic rim of the acetabulum a rugose area might represent the origin of $\mathrm{m}$. quadratus femoris. The pubis and the iliac crest are more complete in the right innominate (MZSP-PV 03), but the bone in general is less complete than its counterpart (Figure 4). The distribution pattern of foramina is different in the two bones, and only one large foramen is seen dorsal to the rectus femoris rugosity in MZSP-PV 03.

\section{Femur}

The left femur (MZSP-PV 01) is complete and well preserved, with signs of abrasion at the tip of the greater trochanter and caudal surface of the inner tibial condyle (Figure 4). The greater trochanter rises proximal to the level of the head and its obliquely truncated lateral surface extends farther distally. The caudal surface of the neck bears a rounded and prominent tuberosity between the trochanteric fossa and the head. The diaphysis is narrower at the middle, expanding gradually towards the extremities. A large nutrient foramen pierces the caudal surface of the bone, midway between the lesser trochanter and the distal articulation, 


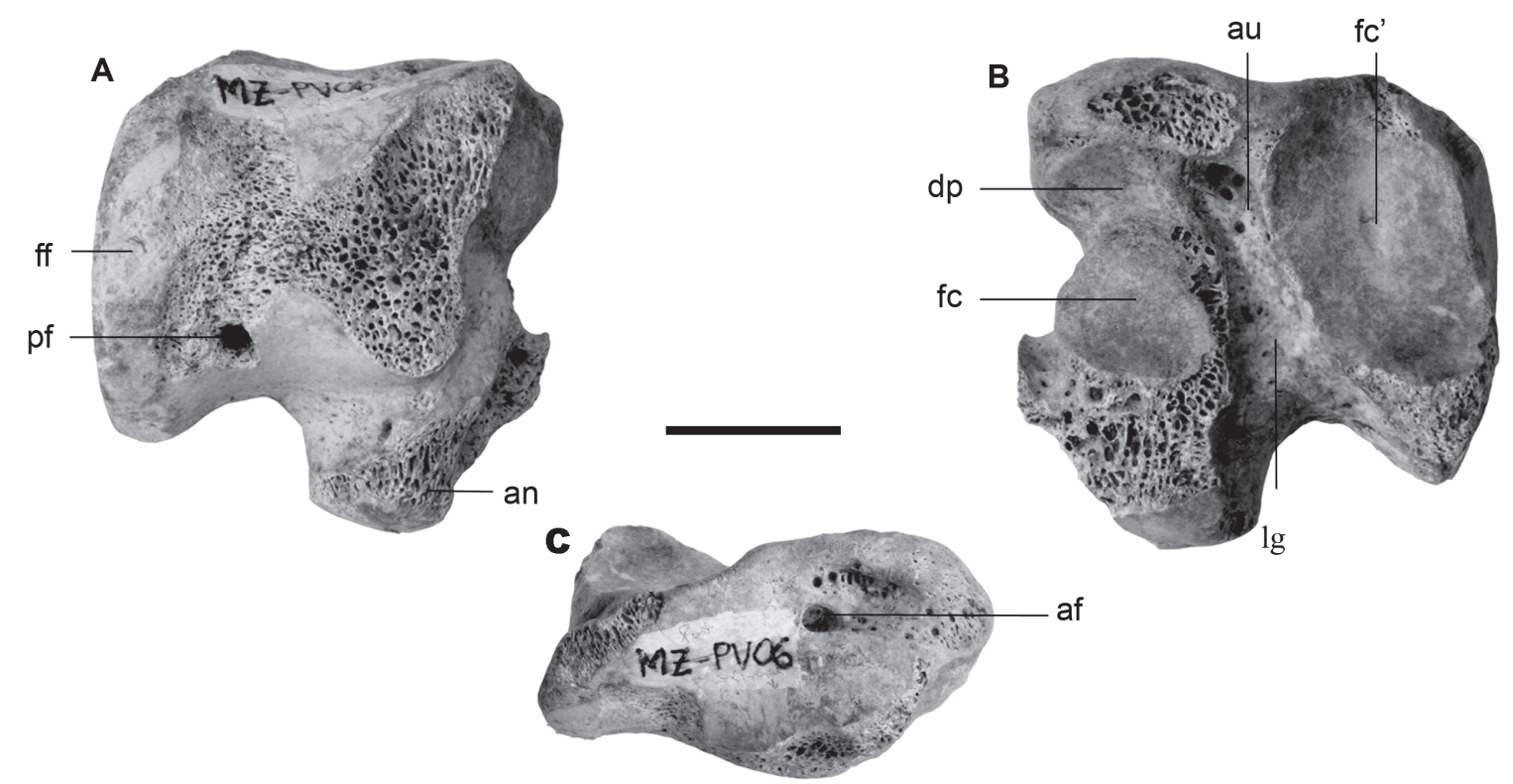

Figura 5. Smilodon populator from Abismo Iguatemi. A-C, MZSP-PV06, right astragalus in proximal (A), distal (B), and caudal (C) views. Abbreviations: af, astragalar foramen; an, articulation for the navicular; au, auxiliar foramina; dp, distoplantar projection; fc, medial facet for calcaneus; fc', lateral facet for calcaneus; ff, articulation for the fibula; Ig, longitudinal groove; pf, proximal foramen. Scale bar = $20 \mathrm{~mm}$.

medial to which a scar for the $\mathrm{m}$. vastus intermedius is seen. The inner tibial articulation is slightly larger than the outer, and both are separated by a narrow intercondylar notch. Directly proximal to the tibial condyles, the caudal surface of the femur bears prominent rugose areas for the origins of $\mathrm{m}$. gastrocnemius.

\section{Astragalus}

The right astragalus (MZSP-PV 06) is a "short-necked" astragalus sensu Merriam \& Stock (1932). It lacks the proximal margin of the trochlea, most of the articulation for the navicular, and the distal facet for the calcaneus (Figure 5). The articular surface for the fibula is broad and slightly concave. A deep longitudinal groove separates the lateral facet from the medial facet for the calcaneus, which is rounded and has a disto-plantar projection. Differently from those described by Merriam \& Stock (1932) and Rodrigues et al. (2004), MZSP-PV 06 has a $3.5 \mathrm{~mm}$ astragalar foramen, a $4 \mathrm{~mm}$ foramen at the proximal surface, and several smaller auxiliary foramina scattered on the plantar surface, as well as surrounding the astragalar foramen.

\section{COMMENTS ON THE SABER-TOOTHED CAT OF ABISMO IGUATEMI}

Given that the specimens share equivalent size, similar preservation, and were found relatively close to one another without duplicated elements, it is suggested that these belong to a single individual. The animal might have entered the fissure partially or completely articulated, either trapped or dragged by pluvial flood as a carcass. Considering the nature of the deposits and the relief of Abismo Iguatemi, the fragmentation and weathering of the fossils seem related to reworking inside the cave.
The dimensions of the studied material are on average greater than those measured by Merriam \& Stock (1932) on North American Smilodon, but approach those of other South American specimens (Burmeister, 1866; Churcher, 1967; Cartelle \& Abuhid, 1989; Méndez-Alzola, 1941). The radius MZSP-PV 04 is subequal in length to that described by Burmeister (1866), but shorter than those measured by Kurtén \& Werdelin (1990) and Méndez-Alzola (1941). It is also broader at the mid-shaft than the radius described by Cartelle \& Abuhid (1989), as well as larger and more robust than the average measured by Meriam \& Stock (1932; Table 1). Similarly, the acetabulum diameter "measured at right angles to long axis of internal notch" of MZSP-PV $02(=53.5 \mathrm{~mm})$ is

Table 1. Measurements $(\mathrm{mm})$ of Smilodon populator radia compared with the data from Merriam \& Stock (1932). Abbreviations: A, greatest length; B, cranial-caudal dimension of the shaft at middle; $\mathbf{C}$, lateral-medial dimension of the shaft at middle; D, greatest cranial-caudal dimension of the distal end; $\mathbf{E}$, greatest lateral-medial dimension of the distal end; e, estimated measurement.

\begin{tabular}{c|cc}
\cline { 1 - 1 } & $\begin{array}{c}\text { MZSP } \\
\text { PV 04 }\end{array}$ & $\begin{array}{c}\text { Average } \\
\text { (maxi-min) }\end{array}$ \\
\cline { 1 - 1 } A & $270 \mathrm{e}$ & $265.7(295-235)$ \\
\cline { 1 - 1 } B & 23 & $20.7(24.6-16.5)$ \\
\cline { 1 - 1 } C & 35 & $31.9(38.8-26.0)$ \\
\cline { 1 - 1 } D & 50 & $42.9(48.2-35.6)$ \\
\cline { 1 - 1 } E & 75 & $58.0(67.3-49.4)$ \\
\cline { 1 - 1 } B/A x 10 & 0.85 & $0.78(0.83-0.70)$ \\
\cline { 1 - 1 } C/A & 0.13 & $0.12(0.14-0.10)$ \\
\cline { 1 - 1 } D/A & 0.19 & $0.16(0.16-0.15)$ \\
\cline { 1 - 1 } E/A & 0.28 & $0.22(0.23-0.20)$ \\
\cline { 1 - 1 } & &
\end{tabular}


Table 2. Measurements $(\mathrm{mm})$ of Smilodon populator astragali. Abbreviations: A, greatest cranial-caudal dimension; B, greatest lateral-medial dimension; $\mathbf{C}$, least distance across the neck.

\begin{tabular}{c|c|c|c|c} 
& $\begin{array}{c}\text { MZSP- } \\
\text { PV 06 }\end{array}$ & $\begin{array}{c}\text { average (max-min) } \\
\text { Merriam \& Stock } \\
\text { (1932) }\end{array}$ & $\begin{array}{c}\text { Rodrigues } \\
\text { et al. } \\
\text { (2004) }\end{array}$ & $\begin{array}{c}\text { Méndez- } \\
\text { Alzola (1941) }\end{array}$ \\
\hline A & 54 & $54.5(61.2-44.6)$ & $55.3 / 50.7$ & 57 \\
\cline { 1 - 1 } B & 54 & $54.75(61.2-46)$ & $55.6 / 50.6$ & 56.1 \\
\cline { 1 - 1 } C & 29 & $26.9(29.5-23.3)$ & - & - \\
\hline
\end{tabular}

on the upper spectrum of the range measured by Merriam \& Stock (1932) for North American forms, and it is close to Argentinean specimens (Méndez-Alzola, 1941; Churcher, 1967). Also the greatest lateral-medial dimension of the sigmoid cavity $(43 \mathrm{~mm})$ and the cranial-caudal dimension of the shaft at the proximal end of the interosseus ligament scar (41 mm) measured in MZSP-PV 05 are within the range of the North American specimens: 51.8 (60.2-41.5) and 39.8 (47.630.0), respectively (Merriam \& Stock, 1932). The dimensions of astragalus also falls within the range of South and North American specimens (Table 2).

The femur (MZSP-PV 01) is larger than those measured by Burmeister (1866), Cartelle \& Abuhid (1989), and Fariña et al. (1998), but more gracile than those studied by Churcher (1967) and smaller than specimens of Kurtén \& Werdelin (1990) and Méndez-Alzola (1941). In relation to the sample measured by Merriam \& Stock (1932), MZSP-PV 01 is always within both size and robustness ranges (Table 3 ), except when it comes to the lateromedial breadth of the proximal extremity, in which case the specimen in question exceeds maximum values of the North American sample. If compared to a specimen of similar length (2009 R-5) within the sample of Merriam \& Stock (1932), MZSP-PV 01 has a much broader proximal extremity, but a narrower distal end. Applying the equations of Anderson et al. (1985) and Anyonge (1993) to MZSP-PV 01, the body mass of the specimen can be estimated as subequal to that of Smilodon bonaerensis in Fariña et al. (1998), i.e., around $285 \mathrm{~kg}$. Such estimation is in the range of $220-360 \mathrm{~kg}$ predicted to $S$. populator by Christiansen \& Harris (2005), who also concluded that this species is heavier than the congenerics $S$. gracilis and $S$. fatalis and also substantially larger than any extant felid.

Based on the cranial sutures, occipital morphology, and molars abrasion, it was proposed that the specimens studied by Hingst-Zaher et al. (2003) represents a subadult. On the contrary, assuming that the skull and postcranial belong to a single individual, the analysis of the postcranial elements suggests that it corresponds to an adult.

The above measurements and comparisons are in agreement with the observations of Paula-Couto (1955), that the South American Smilodon is larger and more robust than the North American form of this taxon. It agrees with the fact that the animal becomes progressively stouter with increased body size (Christiansen \& Harris, 2005). Similar variations have been reported within single species of large living carnivores (Berta, 1985). Accordingly, as also proposed by other authors (Paula-Couto, 1955, 1979; Berta, 1985; Cartelle \&
Table 3. Measurements $(\mathrm{mm})$ of Smilodon populator left femur. Abbreviations: A, greatest length parallel to longitudinal axis; $\mathbf{B}$, cranial-caudal dimension of the head; $\mathbf{C}$, greatest lateral-medial dimension of the proximal end; $\mathbf{D}$, cranial-caudal dimension of the shaft at middle; $\mathbf{E}$, lateral-medial dimension of the shaft at middle; $\mathbf{F}$, greatest cranial-caudal dimension of the distal end; $\mathbf{G}$, greatest lateral-medial dimension of the distal end; $\mathbf{H}$, greatest lateral-medial dimension of the rotular surface; I, greatest lateral-medial dimension of the intercondylar notch; $\mathbf{J}$, greatest lateral-medial dimension of the inner tibial articulation; e, estimated measurement.

\begin{tabular}{c|c|c|c} 
& $\begin{array}{c}\text { MZSP- } \\
\text { PV01 }\end{array}$ & $\begin{array}{c}\text { average (max-min) } \\
\text { Merriam \& Stock } \\
(\mathbf{1 9 3 2})\end{array}$ & Churcher (1967) \\
\hline A & 382 & $367.7(408-317)$ & $354 \mathrm{e}-350$ \\
B & 48 & $44.3(50.7-39.1)$ & $46.6 / 46.2$ \\
C & 111 & $95.5(108.8-82.7)$ & $100.3 \mathrm{e} / 96.8$ \\
D & 34 & $31.5(35.4-26.8)$ & $34.2 / 31.3$ \\
E & 38 & $35.8(40.4-30.1)$ & $41.5 / 37.9$ \\
F & 72 & $73.0(80.3-63.9)$ & $77 \mathrm{e} / 72.4$ \\
G & 83 & $78.5(90.2-65.2)$ & $83.2 \mathrm{e} / 81.1$ \\
H & 42 & $50.4(60-42)$ & $49.8 / 55.7$ \\
I & 22 & $19.7(22.7-14.5)$ & $21.2 / 15.5 \mathrm{e}$ \\
J & 33 & $31.0(35.7-24.9)$ & $30.5 /-$ \\
B/A & 0.126 & $0.121(0.126-0.111)$ & $0.132 / 0.131$ \\
C/A & 0.290 & $0.260(0.273-0.246)$ & $0.277 / 0.283$ \\
D/A & 0.089 & $0.086(0.091-0.079)$ & $0.089 / 0.097$ \\
E/A & 0.099 & $0.098(0.108-0.089)$ & $0.108 / 0.117$ \\
F/A & 0.188 & $0.199(0.209-0.186)$ & $0.207 / 0.217$ \\
G/A & 0.217 & $0.213(0.223-0.192)$ & $0.232 / 0.235$ \\
\hline
\end{tabular}

Abuhid, 1989), comparative analysis of the saber-toothed cat of Abismo Iguatemi does not provide evidence for the separation of the South and North American Smilodon into different species.

\section{ACKNOWLEDGMENTS}

We gratefully acknowledge FAPESP for the financial support; H. El Dine Zaher (MZUSP) for the permission to study the material under his care; R. Fariña for the body mass estimation of MZSP-PV 01; and F. Machado and M. Brandão for contributing with the photos.

\section{REFERENCES}

Anderson, J.F.; Hall-Martin \& Russel, D.A. 1985. Long bone circumference and weight in mammals, birds and dinosaurs. Journal of Zoology, 207:53-61.

Anyonge, W. 1993. Body mass in large extant and extinct carnivores. Journal of Zoology, 231:339-350.

Auler, A. \& Farrant, A.R. 1996. A brief introduction to karst and caves in Brazil. Proceedings of University of Bristol Spaleological Society, 20(3):187-200.

Bergqvist, L.P.; Gomide, M.; Cartelle, C. \& Capilla, R. 1997. Faunas-locais de mamíferos pleistocênicos de Itapipoca/Ceará, Taperoá/Paraíba e Campina Grande/Paraíba. Estudo Comparativo, bioestrationômico e paleoambiental. Revista Universidade de Guarulhos, Geociências, 2(6):23-32.

Berta, A. 1985. The status of Smilodon in North and South America. 
Natural History Museum of Los Angeles County, Contributions to Science, 379:1-15.

Bovard, J.F. 1907. Notes on Quaternary Felidae from California. University of California Publications, Bulletin of the Department of Geology, 5:155-170.

Burmeister, G. 1866. Lista de los mamíferos fósiles del terreno diluviano. Anales del Museo Público de Buenos Aires, 1:121-232.

Cartelle, C. \& Abuhid, V.S. 1989. Novos espécimes brasileiros de Smilodon populator Lund, 1842 (CARNIVORA, MACHAIRODONTINAE): morfologia e conclusões taxonômicas. In: CONGRESSO BRASILEIRO DE PALEONTOLOGIA, 11, 1989. Anais, Curitiba, 1:607-620.

Cartelle, C. \& Hartwig, W.C. 1996. A new extinct primate among the Pleistocene megafauna of Bahia, Brazil. Proceedings of the National Academy of Sciences, 93:6405-6409.

Castro, M.C. 2005. Aspectos paleobiológicos dos depósitos quaternários do Abismo Iguatemi, Vale do Ribeira - SP. Faculdade de Filosofia, Ciências e Letras de Ribeirão Preto, Universidade de São Paulo, Trabalho de Conclusão de Curso, 63 p.

Christiansen, P. \& Harris, J.M. 2005. Body size of Smilodon (Mammalia: Felidae). Journal of Morphology, 266:369-384.

Churcher, C.S. 1967. Smilodon neogaeus en las barrancas costeras de Mar del Plata, Provincia de Buenos Aires. Publicaciones del Museo Municipal de Ciencias Naturales de Mar del Plata, 1(8):245-262.

Dantas, M.A.T. \& Zucon, M.H. 2004. Ocorrência de Glyptodon clavipes Owen, 1839 em Sergipe, Brasil. In: SIMPÓSIO BRASILEIRO DE PALEONTOLOGIA DE VERTEBRADOS, 4, 2004. Boletim de Resumos, Rio Claro, UNESP, p. 17.

Dantas, M.A.T.; Andrade, L.; Zucon, M.H. \& Teodósio, C. 2003. Novo achado da megafauna do Pleistoceno final de Sergipe Fazenda Elefante, Gararu. In: CONGRESSO BRASILEIRO DE PALEONTOLOGIA, 18, 2003. Boletim de Resumos, Brasília, p. 115.

Fariña, R.A.; Vizcaíno, S.F. \& Bargo, M.S. 1998. Body mass estimations in Lujanian (Late Pleistocene-Early Holocene of South America) mammal megafauna. Mastozoologia Neotropical, 5(2):87-108.

Ferreira, N.B. \& Karmann, I. 2002. Descobertas paleontológicas na região de Apiaí-SP. Boletim Informativo Geovisão, 10(4):7-8.

Gomide, M.; Bergqvist, L.P. \& Rêgo, D.D. 1987. O "tigre-dente de sabre” (Smilodon populator) de Itapipoca, Ceará. In: CONGRESSO BRASILEIRO DE PALEONTOLOGIA, 10, 1987. Anais, Rio de Janeiro, p.197-204.

Guerin, C.; Faure, M.; Simões, P.R.; Hugueney, M. \& MourerChauvire, C. 1999. The Pleistocene Palaeontological Site of Toca da Janela da Barra do Antonião (São Raimundo Nonato, Piaui state). Available at <http://www.unb.br/ig/sigep/sitio069/ sitio069english.htm $>$ Accessed in June $28^{\text {th }}, 2008$.

Hingst-Zaher, E.; Ferreira, N.B.; Lessa, G.M. \& Karmann, I. 2003. Primeira ocorrência de Smilodon populator Lund 1842 (Mammalia, Carnivora) no Alto Vale do Ribeira, sul do Estado de São Paulo. In: SIMPÓSIO BRASILEIRO DE PALEONTOLOGIA DE VERTEBRADOS, 3, 2003. Boletim de Resumos, Rio de Janeiro, UERJ, p. 22.

International Committee on Veterinary Gross Anatomical Nomenclature. 2005. Nomina Anatomica Veterinaria. $5^{\mathrm{a}}$ ed. Editorial Committee, Hanover, Germany, Columbia, New York, Gent, Belgium, and Sapporo, Japan, 166 p.
Kurtén, B. \& Anderson, E. 1980. Pleistocene Mammals of North America. New York City, Columbia University Press, 443 p.

Kurtén, B. \& Werdelin, L. 1990. Relationships between North and South American Smilodon. Journal of Vertebrate Paleontology, 10(2): 158-169.

Leidy, J. 1869. The extinct mammalian fauna of Dakota and Nebraska, including an account of some allied forms from other localities, together with a synopsis of the mammalian remains of North America. Journal of the Academy of Natural Sciences of Philadelphia, 7:1-472.

Lessa, G.; Cartelle, C.; Faria, H.D. \& Gonçalves, P.R. 1998. Novos achados de mamíferos carnívoros do Pleistoceno final - Holoceno em grutas calcárias do estado da Bahia. Acta Geologica Leopoldensia, 21(46-47):157-169.

Lund, P.W. 1839. Blik paa Brasiliens Dyreverden för Sidste Jordomvaeltning. Anden Afhandling: Pattedyrene. Lagoa Santa, d 16d. Novbr. 1837. Det Kongelige Danske Videnskaberns Selskabs Naturvidenskabelige og Mathematiske Afhandling, 8:61-144. [Preprint of Lund 1841a.].

Lund, P.W. 1842. Blik paa Brasiliens Dyreverden för sidste Jordomvaeltning. Fjerde Afhandling: Forstsaettelse af Pattedyrene. Danke vidensk. Selsk., 9:137-209.

Lund, P.W. 1950. Memórias sobre a paleontologia brasileira (Revistas e comentadas por Carlos de Paula Couto). Rio de Janeiro, Ministério da Educação e Saúde, Instituto Nacional do Livro, $589 \mathrm{p}$.

Méndez-Alzola, R. 1941. El Smilodon bonaërensis (Muñiz), Estudio osteológico y osteométrico del gran tigre fósil de la pampa comparado con otros félidos actuales y fósiles. Anales del Museo Argentino de Ciencias Naturales "Bernardino Rivadavia”, 40(67):135-252.

Merriam, J.C. \& Stock, C. 1932. The Felidae of Rancho La Brea. Carnegie Institution of Washington, 422:1-231.

Paula-Couto, C. 1955. O "Tigre-dentes-de-sabre" do Brasil. Boletim do Conselho Nacional de Pesquisas, 1:1-30.

Paula-Couto, C. 1979. Tratado de Paleomastozoologia. Rio de Janeiro, Academia Brasileira de Ciências. 590 p.

Paula-Couto, C. 1980b. Fossil Pleistocene to sub-recente mammals from Northeastern Brazil. I - Edentata Megalonychidae. Anais da Academia Brasileira de Ciências, 52(1):143-151.

Paula-Couto, C. 1980a. Pleistocene Mammals from Minais Gerais and Bahia. In: CONGRESSO ARGENTINO DE PALEONTOLOGÍA Y BIOESTRATIGRAFÍA, 2, Y CONGRESSO LATINOAMERICANO DE PALEONTOLOGÍA, 1, 1980. Acta, Buenos Aires, p.193-209.

Piló, L.B. \& Neves, W.A. 2003. Novas datações ${ }^{14}$ C (AMS) confirmam a tese da coexistência do homem com a megamastofauna pleistocênica na região cárstica de Lagoa Santa, MG. In: CONGRESSO BRASILEIRO DE ESPELEOLOGIA, 27, 2003. Anais, Januária, p. 27.

Porpino, K.O.; Santos, M.F. \& Bergqvist, L.P. 2004. Registros de mamíferos fósseis no Lajedo de Soledade, Apodi, Rio Grande do Norte, Brasil. Revista Brasileira de Paleontologia, 7(3):349-358.

Rodrigues, P.H.; Prevosti, F.J.; Ferigolo, J. \& Ribeiro, A.M. 2004. Novos materiais de Carnivora para o Pleistoceno do Estado do Rio Grande do Sul, Brasil. Revista Brasileira de Paleontologia, 7(1):77-86.

Silva, F.M.; Barreto, S.F.; Sá, F.B. \& Silva, A.C. 2003. Levantamento das ocorrências de fósseis de megafauna pleistocênica do estado de Pernambuco. Paleontologia em Destaque, 4:53-54. 